\title{
Cooking quality of upland and lowland rice characterized by different methods
}

\author{
Qualidade culinária do arroz de terras altas e irrigado caracterizado por diferentes métodos
}

\author{
Diva Mendonça GARCIA ${ }^{1}$, Priscila Zaczuk BASSINELLO ${ }^{2 *}$, Diego Ramiro Palmirez ASCHERI ${ }^{3}$, \\ José Luis Ramirez ASCHERI ${ }^{4}$, José Benedito TROVO ${ }^{5}$, Rosário de Maria Arouche COBUCCI ${ }^{6}$
}

\begin{abstract}
Rice cooking quality is usually evaluated by texture and stickiness characteristics using many different methods. Gelatinization temperature, amylose content, viscosity (Brookfield viscometer and Rapid Visco Analyzer), and sensory analysis were performed to characterize culinary quality of rice grains produced under two cropping systems and submitted to different technologies. All samples from the upland cropping system and two from the irrigated cropping system presented intermediate amylose content. Regarding stickiness, BRS Primavera, BRS Sertaneja, and BRS Tropical showed loose cooked grains. Irrigated cultivars presented less viscosity and were softer than upland cultivars. Upland grain samples had similar profile on the viscoamylografic curve, but the highest viscosity peaks were observed for BRS Alvorada, IRGA 417, and SCS BRS Piracema among the irrigated cropping system samples. In general, distinct grain characteristics were observed between upland and irrigated samples by cluster analysis. The majority of the upland cultivars showed soft and loose grains with adequate cooking quality confirmed by sensory tests. Most of the irrigated cultivars, however, presented soft and sticky grains. Different methodologies allowed to improve the construction of the culinary profile of the varieties studied.

Keywords: Oryza sativa L.; texture; stickiness; amylase; gelatinization temperature; cluster.
\end{abstract}

\section{Resumo}

A qualidade culinária do arroz é determinada por aspectos relacionados à textura e à pegajosidade, podendo ser determinada por vários métodos. Sendo assim, efetuaram-se testes de temperatura de gelatinização, teor de amilose, viscosidade (viscosímetro de Brookfield e Analisador Rápido de Viscosidade) e análise sensorial em cultivares de diferentes sistemas de cultivo. Todas as amostras de terras altas e apenas duas do sistema irrigado apresentaram teor de amilose intermediário. Em relação à pegajosidade, apenas as cultivares BRS Primavera, BRS Sertaneja e BRS Tropical apresentaram-se com aspecto de grãos cozidos soltos. As cultivares do sistema irrigado tendem a ser menos duras, pois apresentam menor viscosidade que as cultivares de terras altas. Entre as amostras de terras altas, todas apresentaram perfis similares de curva viscoamilográfica, já em relação aos materiais de irrigado, os maiores picos de viscosidade foram obtidos para BRS Alvorada, IRGA 417 e SCS BRS Piracema. Puderam-se observar características distintas entre os dois sistemas por meio da análise de agrupamento. As cultivares de terras altas indicaram, em sua maioria, características de grãos macios e soltos, confirmadas pelos testes sensoriais. As cultivares de arroz irrigado, em sua maioria, apresentam características de grãos macios e pegajosos. Diferentes metodologias permitiram melhor construção do perfil culinário das amostras estudadas.

Palavras-chave: Oryza sativa L.; textura; pegajosidade; amilose; temperatura de gelatinização; agrupamento.

\section{Introduction}

Rice is grown in many countries all over the world and in addition to its social importance it plays an important role in human nutrition as well as in agricultural economics. Nowadays, consumers are very concerned with milling and cooking quality. Today, there is a large number of varieties and more are being developed to enhance agronomic and technological quality in order to meet consumer demands. According to Guimarães et al. (2006), rice (Oryza sativa L.) is a hydrophilic species adapted to a large number of ecosystems. In Brazil, there are two cropping ecosystems: lowland, irrigated with controlled water flow, and upland rainfield with or without supplementary irrigation.
Differences between these systems have induced variability in rice plant characteristics leading to genotype adaptation. Nowadays, in our globalized world, rice grain quality must be continuously enhanced, identified, and divulged. This is the way to survive in a more demanding and competitive market.

In Brazil, there were great differences in rice quality among varieties from irrigated and upland cropping ecosystems, but with the release of new cultivars from breeding programs, those differences have become more tenuous. According to Ferreira et al. (2005), rice from both systems will play important role in complementing each other with a degree

\section{Received 6/4/2009}

Accepted 27/1/2010 (004145)

1 Instituto Federal Goiano, Campus Morrinhos, BR 153, Km 633, Zona Rural, CEP 75650-000, Morrinhos, GO, Brasil

${ }^{2}$ Embrapa Arroz e Feijão, Escritório Técnico Qualidade de Grãos, CEP 75375-000, Santo Antônio de Goiás, GO, Brasil, E-mail: priscilazb@cnpaf.embrapa.br

${ }^{3}$ Universidade Estadual de Goiás, Unidade Universitária de Ciências Exatas e Tecnológicas, CEP 75001-970, Anapolis, GO, Brasil

${ }^{4}$ Laboratório Reologia, Planta Piloto de Tecnologia de Cereais, Embrapa Agroindústria de Alimentos, CEP 23020-470, Rio de Janeiro, RJ, Brasil

${ }^{5}$ Embrapa Arroz e Feijão, Centro Nacional de Pesquisa em Arroz e Feijão, CEP 75375-000, Santo Antônio de Goiás, GO, Brasil

${ }^{6}$ Universidade Católica de Goiás, Matemática e Física, Goiânia, GO, Brasil

${ }^{*}$ Corresponding author 
of competitiveness not restricted to upland and lowland rice quality only, but also to the degree of organization of the production chain.

Consumer preference is based on the evaluation of quality attributes, which is determined not only by chemical and physical properties of grains, but also by aspects related to the appearance of the product after cooking, such as stickiness and texture (softness or fluffiness). The cooking and textural properties are largely dependent on the chemical composition of cultivars rather than on their physical characteristics (MOHAPATRA; BAL, 2006). Amylose content has been considered one of the most important characteristics in cooking behavior (XIE et al., 2007; ONG; BLANSHARD, 1995a).

Embrapa Rice and Beans is responsible for national rice enhancement programs, and it is conducting breeding projects to increase yield and grain quality. Rice quality is evaluated by testing physical and chemical characteristics, but with regard to the rice breeding program, only milling, market and consumer preference are evaluated as a routine.

Considering that the number of rice lines to be evaluated in the breeding program in a three-month period is very large (around 25,000), researchers are able to perform procedures that respond to some indirect quality indicators only.

The purpose of our study was to apply different tools in grain quality evaluation to characterize milled rice cooking quality in grains harvested from lowland and upland cropping systems and to find divergences or common traits between ten accesses by grouping them according to similarity based on the Ward's clustering method.

\section{Materials and methods}

The experiments were conducted from August to November 2006. The upland cultivars tested were: BRS Primavera, BRS Pepita, BRS Monarca, BRS Sertaneja, and BRS MG Curinga. The irrigated genotypes were: BRA 01305, BRS Tropical, BRS Alvorada, IRGA 417, and BRS SCS Piracema. The upland cultivars were grown at the Capivara farm in Santo Antonio de Goiás, State of Goiás, Brazil, and harvested on April 24, 2006. Those from the irrigated system were cultivated at Palmital Farm, in Goianira, State of Goiás, Brazil, and harvested on May 5, 2006. After drying, the rice samples were shelled and milled with a rice machine (Suzuki model MT). Since these cultivars belonged to the long-slender grain class, they were milled during equal periods of time. After milling, part of samples was milled with mill of knives (Laboratory Mill model 3100) for the tests of Apparent Amylose Content (AAC) and Rapid Visco Analyzer (RVA).

AAC, Gelatinization Temperature (GT), cooking test and sensory analysis were performed in the Grain Quality Laboratory at Embrapa Rice and Beans in Santo Antonio de Goiás. The viscosity test was accomplished at "Universidade Estadual de Goiás" (UEG), in Anápolis, State of Goiás, Brazil. The RVA assay was conducted at Embrapa Food Technology, in Guaratiba, Rio de Janeiro, state of Rio de Janeiro, Brazil. Except for the RVA analysis and the viscosity test, performed with two repetitions, all assays were done with three repetitions.

GT was estimated according to the methodology developed by Martinéz and Cuevas (1989) and adapted by Embrapa Rice and Beans using $1.7 \% \mathrm{KOH}$ as the alkali reagent and the following rice controls: Colombia 1 (high GT), Bluebonnet 50 (intermediate GT), and IR 8 (low GT).

The AAC test was determined through the iodometric technique following the methodology developed by Martinéz and Cuevas (1989) and adapted by Embrapa Rice and Beans using a solution of iodine/potassium iodate as the indicator and a commercial potato amylose as standard. The complex formed was measured at the visible wavelength $\lambda=620 \mathrm{~mm}$ using a spectrophotometer. The following standard samples were used for comparison: Colômbia 1 (low AAC), Bluebonnet 50 (intermediate AAC), and IR 8 (high AAC).

The viscosity was evaluated based on the performance of BRS Primavera, which is considered a reference for upland rice quality (MORAIS et al., 2003), and it was used in a preliminary test to set the rheological conditions of analysis. Firstly, $50 \mathrm{~g}$ of rice were cooked in $200 \mathrm{~mL}$ of distilled water for 10 minutes, and then it was mixed to different proportions of water to reach an adequate torque value between 10 and $90 \%$ during a viscosity test making use of a Brookfield Viscometer (BROOKFIELD, 2006). As a result of this optimization, the ideal proportion was obtained with $72 \mathrm{~mL}$ of distilled water to $20 \mathrm{~g}$ of cooked rice that was homogenized using a domestic mixer (Black \& Decker, model SB 40). The rheological measures were obtained according to the methodology described in the instruction manual of the Brookfield digital DV-II+ (with a small sample adapter and spindle SC4-18).

The RVA (Rapid Visco Analyzer 4, Newport Scientific PTY LTD, Sydney, Australia) analysis was performed to obtain the viscoamylographic curve of the rice starch. To perform this test, crude samples were weighed (50 g), identified, and sent to Embrapa Food Technology. The methodology described by AACC (AMERICAN..., 2000) was followed.

The sensory analysis for the texture and stickiness attributes were based on two methods: a) cooking test based on small sample and six trained panelists evaluation using the structured scale method (verbal \& bipolar: 1 - Extremely soft, 7 - Extremely hard; 1 - Extremely loose, 7 - Extremely Sticky). To improve efficiency, three replicates were used for each of the two attributes. The samples were prepared according to the methodology suggested by Lima et al. (2006) using $6 \mathrm{~g}$ of rice cooked in Petri dishes for 30 minutes in $18 \mathrm{~mL}$ of distilled water, under vapor condition, in a semi-industrial pan (Golden Kitchen Baspra); b) cooking test simulating typical consumer rice preparation according to the methodology used in routine analysis at Embrapa Rice and Beans, which was adapted from Martinéz and Cuevas (1989): $570 \mathrm{~mL}$ of distilled water, $2 \mathrm{~g}$ of salt, and $60 \mathrm{~mL}$ of soybean cooking oil were added to $300 \mathrm{~g}$ of rice and let to cook for 20 minutes, approximately. The rice stickiness was evaluated right after cooking, whereas texture was analyzed 30 minutes after cooking. 
Data analyses were performed using SAS 9.1 (2003) (SAS institute Inc., Cary, NC). Mean comparisons between cultivars and tasters for texture and stickiness characteristics were performed using the Tukey Test at 5\% level of probability. The cultivars were clustered using the Ward's clustering method (WARD, 1963 apud OLIVEIRA, 2008), which consisted of data clustering with the minimum standard deviation between the values of each group.

\section{Results and discussion}

Physicochemical and sensory analysis may give reliable subsidies to describe the sensory, cooking, and processing characteristics of rice cultivars. The samples from different cultivating cropping systems were analyzed for different quality parameters individually or together whenever possible. The results are shown in Table 1.

All cultivars from the upland ecosystem presented intermediate GT corresponding to a range of 69 to $73{ }^{\circ} \mathrm{C}$. Similar results were found by Fonseca et al. (2004) for cultivar BRS MG Curinga and by Ferreira and Pinheiro (2003) for cultivar BRS Primavera, both upland rice cultivars. According to Santos et al. (1999), cultivars with intermediate GT showed a good culinary behavior; and consequently it became a requirement for the release of new cultivars in Brazil. According to these authors, when a rice variety presents high gelatinization temperature, it means that its grains need more water and time to cook, whereas the cultivars with intermediate or low gelatinization temperatures need less water and time to be cooked resulting less energy input and expense. Cultivars from the irrigated ecosystem showed low GT, except for BRS Alvorada. The low GT genotypes, BRA 01305, BRS Tropical, IRGA 417, and SCS BRS Piracema showed good capability of water absorption; therefore they are expected to cook faster with little water volume and to release soft grains with a tendency to stickiness if overcooked. IRGA 417 is a standard lowland cultivar for the state of Rio Grande do Sul in the South Brazil, and its low GT characteristic was also described by Fagundes et al. (2004).

All samples from the upland and two from the irrigated ecosystems presented intermediate AAC (between 23 and 27\%), and three others from the irrigated system showed high AAC (between 28 and 33\%) according to the "Centro Internacional de Agricultura Tropical" (CIAT) amylose classification scale (MARTINEZ; CUEVAS, 1989). Those grains tend to become hard after cooking with a high probability of retrogradation.

Considering that the intermediate amylose content is a desirable trait for the Brazilian rice market (VIEIRA, 2004), the majority of the studied samples showed ideal stickiness and texture characteristics with fluffy and soft cooked rice grains. According to Pereira and Rangel (2001), low amylose rice tends to be soft and sticky in comparison to the soft and fluffy intermediate amylose rice. Similar results were found by Ferreira and Pinheiro (2003) for the upland rice grain quality standard, BRS Primavera.

It is important to emphasize that the existing data about amylose content are expressed as "apparent" (JULIANO, 1993) without taking into account the interference of iodine-amylopectin complex in the test, which raises doubt about the adequacy of such method in assisting a rice breeding program once the values obtained for amylose could be overestimated. The different amylopectin structures may explain why rice that possesses similar amylose contents can have different textural properties (ONG; BLANSHARD, 1995a; CHAMPAGNE et al., 1999). However, this property can be related to the intrinsic characteristic of the studied cultivars that influences the structural arrangement of starch leading to differences in texture. Another hypothesis may be associated to the presence of a greater area of amorphous regions in starch granules. Rice cooking may promote dispersion of the crystallites in the starch granule and facilitate interactions with the longer chain components. Therefore, it is possible to detect more sutil differences in rice texture (ONG; BLANSHARD, 1995b).

The BRS Primavera showed average values of $25.60 \mathrm{cP}$ at $50 \mathrm{rpm}$ for pasta viscosity. Hence, in the present work, it was defined that cultivars with viscosity values above $25.60 \mathrm{cP}$ have a tendency to be more viscous when compared to those considered standard; they should absorb more water and become harder after cooking. Among the highland cultivars, BRS Pepita had the highest viscosity value and its rice pasta absorbed more water than the others and was stickier. When cultivars from both cropping systems were compared, those

Table 1. Physicochemical, cooking and sensory analysis results of rice cultivars from two cropping systems.

\begin{tabular}{|c|c|c|c|c|c|c|c|c|c|c|}
\hline \multirow{2}{*}{$\begin{array}{c}\text { Cropping } \\
\text { systems }\end{array}$} & \multicolumn{6}{|c|}{ Sensory analysis } & \multicolumn{2}{|c|}{ Cooking test } & \multicolumn{2}{|c|}{ RVA } \\
\hline & Cultivars & $\mathrm{T}^{1}$ & $\mathrm{St}^{2}$ & $\mathrm{AA}^{3}$ & $\mathrm{GT}^{4}$ & Viscosity (cP) & $\mathrm{T}^{1}$ & $\mathrm{St}^{2}$ & Setback $^{5}$ & Breakdown $^{6}$ \\
\hline \multirow[t]{5}{*}{ Upland } & BRS Primavera & SO & LO-SL & I & I & 25,60 & $\mathrm{Hr}$ & LO & 83,63 & 38,50 \\
\hline & BRS Pepita & $\mathrm{SO}$ & St & I & I & 40,39 & $\mathrm{Hr}$ & SS & 49,58 & 45,58 \\
\hline & BRS Monarca & $\mathrm{SO}$ & SL-St & I & I & 30,07 & $\mathrm{Hr}$ & SS & 57,29 & 31,08 \\
\hline & BRS Sertaneja & $\mathrm{SO}$ & LO-SL & I & I & 30,11 & $\mathrm{Hr}$ & LO & 67,37 & 48,33 \\
\hline & BRS MG Curinga & $\mathrm{SO}$ & VS & I & I & 24,28 & $\mathrm{Hr}$ & St & 36,33 & 44,58 \\
\hline \multirow[t]{5}{*}{ Irrigated } & BRA 01305 & SO & St & $\mathrm{H}$ & $\mathrm{Lw}$ & 20,71 & $\mathrm{Hr}$ & SS & 48,87 & 5,25 \\
\hline & BRS Tropical & $\mathrm{SO}$ & SL & $\mathrm{H}$ & $\mathrm{Lw}$ & 23,85 & $\mathrm{Hr}$ & LO & 37,33 & 4,45 \\
\hline & BRS Alvorada & ES-SO & VS & $\mathrm{H}$ & I & 23,98 & $\mathrm{Hr}$ & St & 63,20 & 3,92 \\
\hline & IRGA 417 & ES-SO & SL-St & I & $\mathrm{Lw}$ & 19,00 & $\mathrm{Hr}$ & SS & 102,29 & 14,70 \\
\hline & SCS BRS Piracema & $\mathrm{SO}$ & St & I & $\mathrm{Lw}$ & 22,58 & $\mathrm{Hr}$ & SS & 84,54 & $-1,54$ \\
\hline
\end{tabular}

\footnotetext{
${ }^{1}$ Texture (SO-Soft; ES-Extremely soft; Hr-Hard); ${ }^{2}$ Stickiness (LO-Loose; SL-Slightly loose; St-Sticky; VS-Very sticky; SS-Slightly sticky); ${ }^{3}$ Apparent amylose content (I-Intermediate; H-High);
}

${ }^{4}$ Gelatinization Temperature (I-Intermediate; Lw-Low); ${ }^{5}$ Setback (Difference between final and maximum viscosity); ${ }^{6}$ Breakdown (Difference between maximum and minimum viscosity). 
from the irrigated system tended to be harder and more viscous than those from the upland system. Among the samples from the irrigated system, the South standard cultivar called IRGA 417 had viscosity of $19.00 \mathrm{cP}$. Thus, the other varieties from the same cropping system with viscosity value higher than $19.00 \mathrm{cP}$ tend to be harder.

The viscous behavior (Figures 1 and 2) is related to the rotation speed of the pin used (S18). The viscosity curves had the same pattern even with variations on the rotation speed, exponentially reduced with the increase in speed measured in $\mathrm{rpm}$. Those values enhance the difference of the viscosity values studied for both cultivar groups. The cultivar BRS MG Curinga showed the lowest viscosity value and the BRS Pepita showed the highest one. Among the lowland group, BRS Alvorada presented the highest viscosity value at $50 \mathrm{rpm}$, and declined with other speed values. Such behavior could be attributed to deficiencies in the process of pasta homogenization once the obtained rice pasta was grumous. The Brookfield viscometer releases the viscosity behavior in different speeds; therefore, we decided to calculate the deformity rate in order to obtain the absolute viscosity of rice (BROOKFIELD, 2006).

All cultivars from the upland system showed similar patterns in the viscoamylographic curve by the RVA analysis; however, the cultivars BRS Pepita, BRS Sertaneja and BRS MG Curinga had the highest average values for maximum viscosity suggesting that they might have a more resistant starch structure to breakdown, which implicates the need for more water to increase the volume of starch granules and, most probably, higher GT value. Those cultivars along with BRS Primavera showed the highest values for final viscosity or a higher tendency to retrogradation, suggesting higher AAC. However, taking

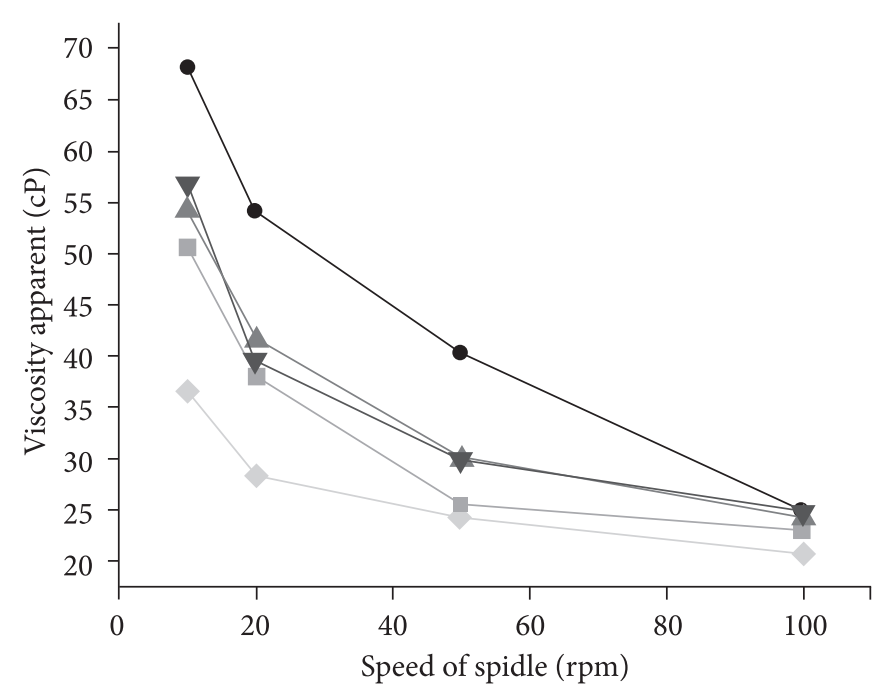

Varieties of rice
- BRS Pepita $\quad-$ BRS Primaveira
$\neg$ BRS Sertaneja - BRS-MG Curinga
- BRS Monarca

Figure 1. Apparent viscosity behavior of rice grains from the upland cropping system. into account the setback values related to increased viscosity and maximum viscosity, it was observed that they were higher BRS Primavera, BRS Monarc, and BRS Sertaneja indicating that these cultivars may be harder than the others.

When analyzing the breakdown RVA mean values (structure breakage and liquefying phase), a similar behavior was observed between the upland rice cultivars, but the lowest ones were obtained for BRS Primavera, BRS Monarca and BRS MG Curinga suggesting the existence of a more fragile starch structure with a molecular organization that collapses fast.

The RVA curves is one of the most useful tools for rapidly and reproducibly assigning the different rice cooking quality classes, but they are probably underutilized because the biological and rheological contributions of starch and protein polymers and lipids to forming the curve are unknown. Hence, understanding how the curve is formed is the first step in determining how the parameters of the curve can be translated into sensory or processing attributes (FITZGERALD et al., 2003).

In the cultivars from the irrigated cropping system, the highest viscosity peaks were obtained with BRS Alvorada, IRGA 417, and SCS BRS Piracema; however, IRGA 417 showed intermediate GT.

Based on the RVA profile characteristics, the starch from BRS Tropical started the gelatinization process around $90^{\circ} \mathrm{C}$, which was the highest value when compared to other lowland genotypes, but it presented the lowest maximum viscosity $(70,50 \mathrm{cP})$ value. The three highest maximum viscosity cultivars also presented the highest final viscosities and setback values indicating higher tendencies to retrogradation and consequent

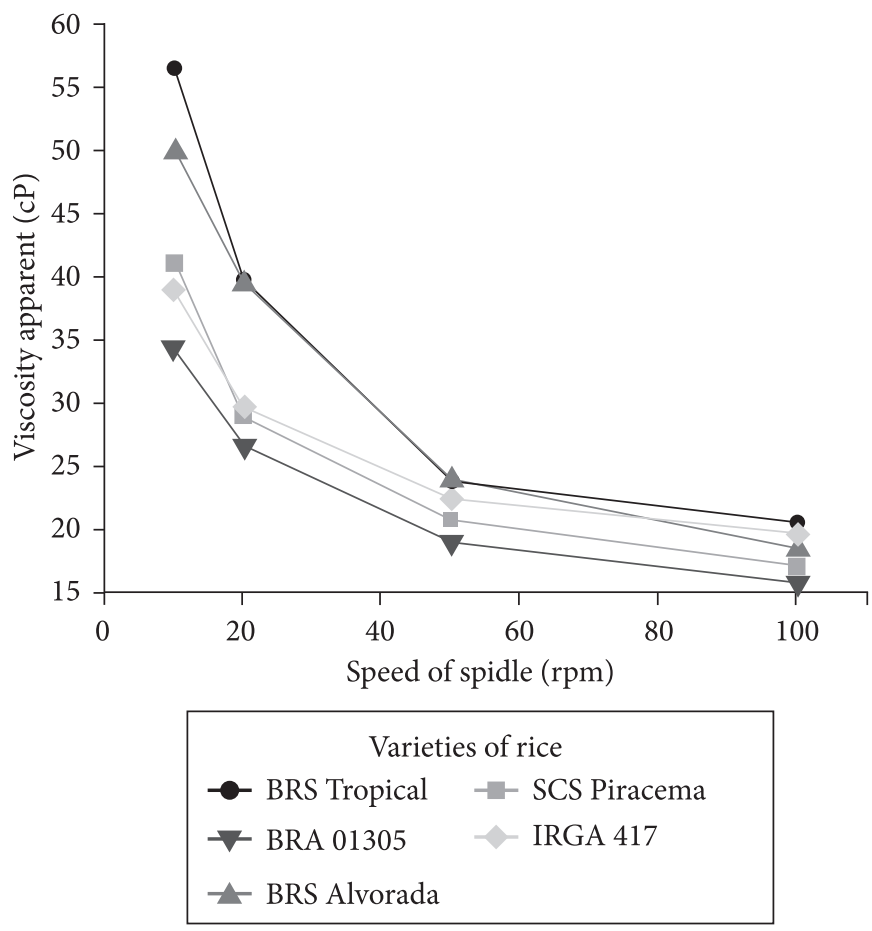

Figure 2. Apparent viscosity behavior of rice grains from the irrigated cropping system. 
higher AAC expected values; this was only observed for BRS Alvorada (high AAC). Ong and Blanshard (1995b) showed that the the rice samples hardness after cooking was correlated with the RVA setback values. The lower thesetback values, the lower the retrogradation and the higher the expected amylopectin content. However, Champagne et al. (1999) did not find a correlation between the texture profile of cooked rice by the sensory trained panel and the one that resulted from RVA. BRA 0135 and BRS Tropical showed lower final viscosities and setback values in a proportional relationship to maximum viscosity (which is expected). Nonetheless, the chemical test indicated higher AAC values. These cultivars also scored the lowest breakdown values demonstrating their ability to rapidly disorganize their starch structure to imitate retrogradation during the cooling process.

With regard to rice preparation, the cooking test is a very common tool adopted by Brazilian rice breeding programs to classify rice quality because it reflects the cooking profile of the product obtained by housewives. However, it does not always correlate with physicochemical tests and should be better standardized once its procedure faces some uncontrolled varying water amount and temperature conditions and depends on the operator evaluation, which makes it a very subjective test. On the other hand, when the texture of a sample is analyzed after being cooled to room temperature, it can be affected by a starch retrogradation process that might take place depending on the starch molecular arrangement and amylose/amylopectin proportion (CHUNG et al., 2008), which is also tightly related to genetic variety.

Stickiness and texture mean values obtained from the sensory test were compared using the Tukey Test at 5\% level of probability. The data presented in Table 2 indicate that the cultivars from both cropping systems do not present texture differences and are all fluffy. With regard to the attribute stickiness, BRS Primavera and BRS Sertaneja were significantly softer than the others, and BRS Alvorada, BRS MG Curinga, and BRA 01305 were stickier, also differing from the others.

BRS Alvorada showed different stickiness characteristics in relation to the other cultivars from the same cropping system,

Table 2. Comparison of texture and stickiness of cooked rice genotypes according to sensory analyses. ${ }^{1}$

\begin{tabular}{|c|c|c|c|}
\hline $\begin{array}{c}\text { Cropping } \\
\text { system }\end{array}$ & Cultivars & Texture & Stickiness \\
\hline \multirow[t]{5}{*}{ Upland } & BRS Primavera & $2,22 \mathrm{SO}^{\mathrm{a}}$ & $3,67{\mathrm{LO}-S L^{\mathrm{d}}}$ \\
\hline & BRS Pepita & $2,16 \mathrm{SO}^{\mathrm{a}}$ & $5,11 \mathrm{St}^{\mathrm{b}}$ \\
\hline & BRS Monarca & $2,11 \mathrm{SO}^{\mathrm{a}}$ & 4,72 SL-St ${ }^{b c}$ \\
\hline & BRS Sertaneja & $2,00 \mathrm{SO}^{\mathrm{a}}$ & $3,67 \mathrm{LO}-\mathrm{SL}^{\mathrm{d}}$ \\
\hline & BRS MG Curinga & $2,28 \mathrm{SO}^{\mathrm{a}}$ & $6,05 \mathrm{VS}^{\mathrm{a}}$ \\
\hline \multirow[t]{5}{*}{ Irrigated } & BRA 01305 & $2,00 \mathrm{SO}^{\mathrm{a}}$ & $5,00 \mathrm{St}^{\mathrm{a}}$ \\
\hline & BRS Tropical & $2,11 \mathrm{SO}^{\mathrm{a}}$ & $4,33 \mathrm{SL}^{\mathrm{c}}$ \\
\hline & BRS Alvorada & $1,83 \mathrm{ES}^{-\mathrm{SO}^{\mathrm{a}}}$ & $6,11 \mathrm{VS}^{\mathrm{a}}$ \\
\hline & IRGA 417 & $1,94 \mathrm{ES}-S O^{\mathrm{a}}$ & $4,83 \mathrm{SL}_{-} \mathrm{St}^{\mathrm{bc}}$ \\
\hline & SCS BRS Piracema & $2,05 \mathrm{SO}^{\mathrm{a}}$ & $5,11 \mathrm{St}^{\mathrm{b}}$ \\
\hline
\end{tabular}

${ }^{1}$ Means with different letters in the column are significantly different according to Tukey Test at 5\%. ( $<$ < 0.05); ES-Extremely soft; SO- Soft; LO-Loose; SL-Slightly loose; St-Sticky; VS-Very sticky. and it was very sticky. The IRGA 417 had similar characteristics to the cultivars from the irrigated cropping system; it was slightly fluffy and sticky.

The Tukey test was used to analyze the sensory panel evaluation pointed out differences among the sensory scores obtained from different panelists (Table 3). Despite the general tendency among the panelists to be consistent in scoring texture, the statistical mean comparison evidenced a significantly different score given by the forth panelist. According to Della Modesta et al. (2002), differences among panelists could be attributed to psychological factors affecting sensorial perception. They also stated that a panel of trained panelists has other responsibilities besides their participation in the sensory analysis, and it is necessary to find ways to keep their interest and motivation during the evaluation program.

The advantage of performing a descriptive sensory analysis using the structured scale is the possibility of applying statistical analysis on a small number of samples in less time.

In general, varieties from the upland cropping system had different physicochemical and culinary behavior from the lowland cultivars. Through the Ward's method, it was possible to generate clusters with well defined regions to minimize internal differences in each group allowing the observation of proximities of cultivars with similar characteristics with a clear panorama of the studied traits, as can be seen in Figure 3a. In the general cluster analysis, in which all quality parameters studied were considered, we could observe the presence of two main groups: highland and lowland; however, in a deeper analyses, the upland cultivar BRS Sertaneja presented the closest behavior to the reference BRS Primavera, whereas for the lowland system, the BRS Alvorada was the most similar to IRGA 417 profile in terms of general grain quality. Sensory analysis (Figure $3 \mathrm{~b}$ ) data indicated larger differences between the samples, and it is considered a more sensitive method. As can be noticed, the cultivars BRS Primavera and BRS Sertaneja were grouped together by the sensory analyses as well as BRS Pepita, SCS BRS Piracema, and the rice breeding line BRA 01305. On the other hand, the same clusters were not exactly formed when submitting RVA data to the Ward's method, which might be related to other starch characteristics that influence grain quality regarding special interests or industry preference.

The rice breeding program has released the BRS Sertaneja to gradually replace BRS Primavera at the Brazilian market. That cultivar gathers the desired agronomical and grain quality

Table 3. Comparison of rice texture and stickiness classification among panelists. ${ }^{1}$

\begin{tabular}{cll}
\hline Panelist & \multicolumn{1}{c}{ Texture } & \multicolumn{1}{c}{ Stickiness } \\
\hline 1 & $1,97{\mathrm{ES}-\mathrm{SO}^{\mathrm{a}}}^{\mathrm{a}}$ & $4,90 \mathrm{SL}^{-} \mathrm{St}^{\mathrm{ab}}$ \\
2 & $2,03 \mathrm{SO}^{\mathrm{a}}$ & $5,00 \mathrm{St}^{\mathrm{ab}}$ \\
3 & $1,97{\mathrm{ES}-\mathrm{SO}^{\mathrm{a}}}^{\mathrm{a}}$ & $4,77 \mathrm{SL}-\mathrm{St}^{\mathrm{b}}$ \\
4 & $2,60 \mathrm{SO}^{\mathrm{SS}}{ }^{\mathrm{b}}$ & $5,00 \mathrm{St}^{\mathrm{ab}}$ \\
5 & $1,90 \mathrm{ES}^{\mathrm{S}} \mathrm{SO}^{\mathrm{a}}$ & $4,30 \mathrm{SL}^{\mathrm{c}}$ \\
6 & $1,97 \mathrm{ES}^{\mathrm{S}} \mathrm{SO}^{\mathrm{a}}$ & $5,20 \mathrm{St}^{\mathrm{a}}$
\end{tabular}

${ }^{1}$ Means followed by different letters, in the column are significantly different according to Tukey Test at the $5 \%$ level of probability ( $<<0.05$ ); ES- Extremely soft; SO- Soft; SSSlightly soft; SL- Slightly loose; St- Sticky. 
Clusters General analysis

(a)
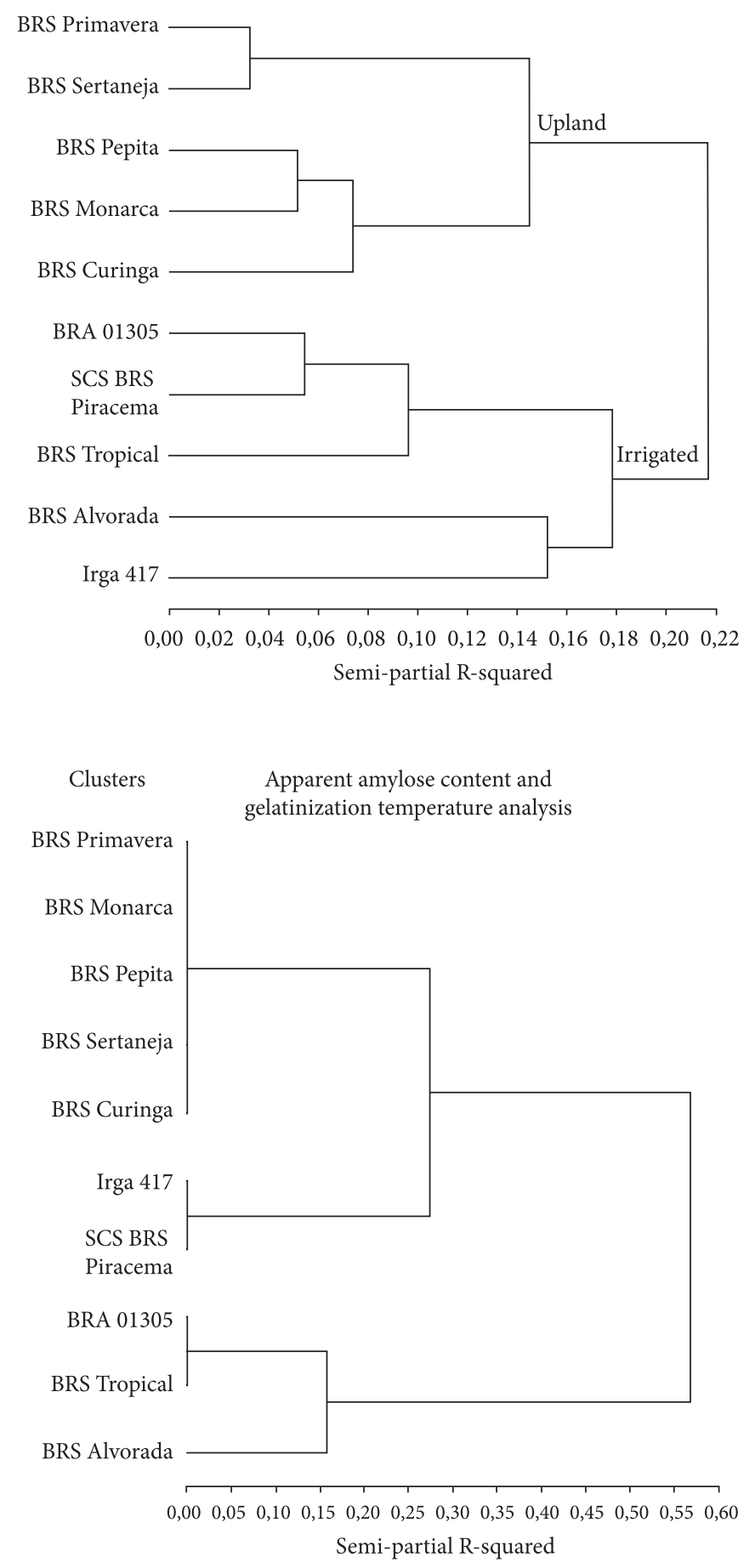

Clusters Sensory analysis

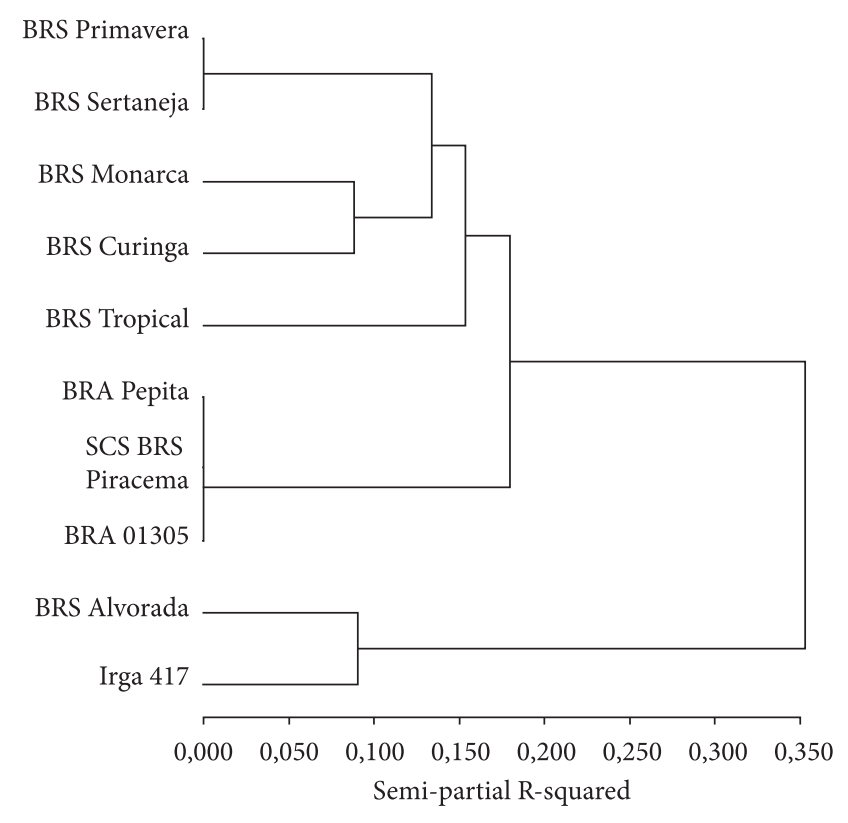

Clusters Rapid visco analyzer

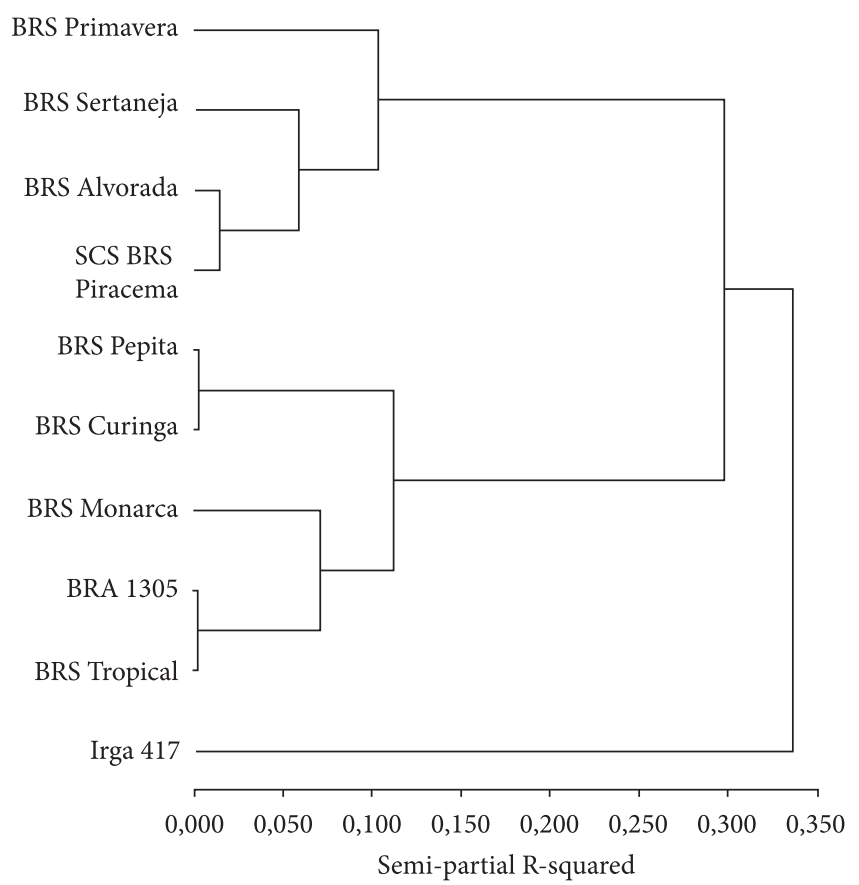

Figure 3. Upland and lowland rice cultivars clustering by Ward's method for grain quality parameters: general analysis, sensory analysis, amylase and gelatinization temperature contents, and RVA analysis.

characteristics (BRESEGHELLO et al., 2006) confirmed by the sensory grouping tests.

With the exception of AAC and GT analyses, IRGA 497, a standard cultivar for grain quality in southern Brazil (FAGUNDES et al., 2004) demonstrated a very different behavior in cluster analyses involving general evaluation, sensory tests, and RVA compared to BRS Primavera and BRS
Sertaneja, both considered reference in terms of grain quality among upland cultivars. These results may be explained by the distinguished precision and sensitivity observed in the sensory test involving the human factor, as well as to the gelatinization and viscosity aspects emphasized by the RVA in opposition to chemical tests such as AAC and GT that reveal indirect cooking patterns subjected to misinterpretations. Other factors that 
were not considered in the indirect tests could have influenced the test results, such as genotype $\times$ environment interactions, in which prevalent field ambient conditions may interfere in post harvest cooking behavior. The water availability during grain production, for instance, greatly influences starch granule swelling during panicle formation. Samples from irrigated rice may require differentiated cooking patterns to exhibit the desired culinary behavior, such as decreased water amounts and cooking time, to fully adopt their quality profile. This is especially important for samples presenting low GT, in which faster starch hydration and shorter cooking time are expected. These rice cultivars may be easily overcooked becoming more viscous and stickier. Analytical tools available for rice grain evaluation are not always efficient to discriminate against differences in grain cooking behavior observed in the samples from different cropping systems or within the same system.

\section{Conclusions}

The studied rice varieties from the upland cropping system showed good culinary quality with soft and fluffy cooked grains. On the other hand, most of the lowland rice cultivars presented soft and sticky cooked grains. It is important to consider different responses or information in order to better evaluate the cooking quality of an individual rice variety or a group of rice varieties from the same production system.

\section{Acknowledgements}

The authors are thankful to panelists who participated in sensory analyses, to rice breeder Dr. Orlando Peixoto de Morais for the milled samples donation, and Dr. Jaison Pereira de Oliveira for the cluster statistical analyses, all from Embrapa Rice and Beans in Santo Antonio de Goiás, Goias State, Brazil.

\section{References}

AMERICAN ASSOCIATION OF CEREAL CHEMISTS - AACC. Method 61-02. In: AACC. Approved Methods of the AACC. 10. ed. Saint. Paul: American Association of Cereal Chemists, 2000.

BRESEGHELLO, F. et al. BRS Sertaneja: cultivar precoce de arroz de terras altas. Comunicado Técnico/Embrapa Arroz e Feijao, v. 133, 2006.

BROOKFIELD. Brookfield DV-II+ programmable viscometer. Operating instructions. Middleboro: Brookfield Engineering Laboratories, Inc. (Manual, n. M/97-164). Disponível em: <www. brookfielengineering.com>. Acesso em: 24 nov. 2006.

CHAMPAGNE, E. T. et al. Correlation between cooked rice texture and rapid visco analyzer measurements. Cereal Chemistry, v. 76, n. 5, p. 764-771, 1999. http://dx.doi.org/10.1094/CCHEM.1999.76.5.764

CHUNG, J-H. et al. Effects of molecular size and chain profile of waxy cereal amylopectins on paste rheology during retrogradation. Carbohydrate Polymers, n. 71, p. 365-371, 2008. http://dx.doi. org/10.1016/j.carbpol.2007.05.018

DELLA MODESTA, R. C. et al. Perfil sensorial de alguns genótipos de arroz brasileiro, da safra 1999/2000. In: CONGRESSO DA CADEIA PRODUTIVA DE ARROZ, 1.; REUNIÃO NACIONAL
DE PESQUISA DE ARROZ - RENAPA, 7., 2002, Florianópolis. Anais... Santo Antônio de Goiás: Embrapa, 2002 . vo. 1. p. 48-50.

FAGUNDES, P. R. R. et al. Cultivares de arroz irrigado para o Brasil. In: MAGALHÃES JÚNIOR, A. M.; GOMES, A. S.; SANTOS, A. B. (Ed.). Sistema de cultivo de arroz irrigado no Brasil. Pelotas: Embrapa Clima Temperado, 2004. p. 89-109.

FERREIRA, C. M.; PINHEIRO, B. S. Possíveis cenários de produção de arroz no Brasil e no Mercosul. In: CONGRESSO DA CADEIA PRODUTIVA DE ARROZ, 1.; REUNIÃO NACIONAL DE PESQUISA DE ARROZ - RENAPA, 7., 2002, Florianópolis. Anais... Santo Antônio de Goiás: Embrapa, 2003. vol. 2. p. 169-185.

FERREIRA, C. M. et al. Importância econômica e social do arroz no Brasil. In: FERREIRA, C. M.; SOUSA, I. S. F.; MÉNDEZ DEL VILLAR, P. (Ed.). Desenvolvimento tecnológico e dinâmica da produção de arroz de terras altas no Brasil. Santo Antônio de Goiás: Embrapa Arroz e Feijão, 2005. p. 9-26.

FITZGERALD, M. A. et al. Viscosity of rice flour: a rheological and biological study. Journal Agricultural and Food Chemistry, n. 51, p. 2295-2299, 2003. PMid:12670173. doi:10.1021/jf020574i

FONSECA, J. R. et al. Pontos de Colheita e Características das Cultivares de Arroz de Terras Altas "BRS MG Curinga" e "BRS Liderança”. Comunicado Técnico / Embrapa Arroz e Feijão, v. 79, 2004.

GUIMARÃES, C. M. et al. Sistemas de cultivo. In: SANTOS, A. B.; STONE, L. F.; VIEIRA, N. R. A. (Ed.). A cultura do arroz no Brasil. Santo Antônio de Goiás: Embrapa Arroz e Feijão, 2006. p. 53-96.

JULIANO, B. Rice in human nutrition. Roma: FAO, 1993. Disponível em: <http://www.fao.org/inpho/vlibrary.htm>. Acesso em: 30 nov. 2009.

LIMA, C. H. A. M. et al. Seleção e treinamento de uma equipe de provadores para avaliação sensorial de diferentes cultivares de arroz. Boletim de Pesquisa e Desenvolvimento / Embrapa Arroz e Feijão, v. 23, 2006.

MARTINÉZ, C.; CUEVAS, F. Evaluación de la calidad culinária y molinera del arroz: guia de estúdio para ser usada como complemento de la unidad auditutorial sobre el mismo tema. 3. ed. Cali: Centro Internacional de Agricultura Tropical, 1989. 73 p.

MOHAPATRA, D.; BAL, S. Cooking quality and instrumental textural attributes of cooked rice for different milling fractions. Journal of Food Engineering, n. 73, p. 253-259, 2006. http://dx.doi. org/10.1016/j.jfoodeng.2005.01.028

MORAIS, O. P. et al. Extensão de recomendação da cultivar de arroz de terras altas "BRS Soberana para Goiás". Comunicado técnico / Embrapa Arroz e Feijão, v. 73. 2003.

OLIVEIRA, J. P. et al. Parecença entre acessos tradicionais de feijão carioca utilizando o método de Ward. In: CONGRESSO NACIONAL DE PESQUISA DE FEIJÃO, 9., 2008, Campinas: Anais... Campinas: IAC, 2008. p. 402-405. CD-ROM. (IAC. Documentos, 85).

ONG, M. H.; BLANSHARD, J. M. V. Texture determinants of cooked, parboiled rice. I: Rice starch amylose and the fine structure of amylopectin. Journal of Cereal Science, n. 21, p. 251-260, 1995a. http://dx.doi.org/10.1006/jcrs.1995.0028 
ONG, M. H.; BLANSHARD, J. M. V. Texture determinants of cooked, parboiled rice. II: Physicochemical properties and leaching behaviour of rice. Journal of Cereal Science, n. 21, p. 261-269, 1995b. http://dx.doi.org/10.1006/jcrs.1995.0029

PEREIRA, J. A.; RANGEL, P. H. N. Produtividade e qualidade de grãos de arroz irrigado no Piauí. Ciência e Agrotecnologia, v. 25, n. 3 , p. 569-575, 2001.

STATISTICAL ANALISYS SYSTEM INSTITUTE - SAS. SAS System for Windows. Versão 9.1. Cary: SAS Institute Inc., 2003. 1 CD-ROM.
SANTOS, A. B. et al. Manejo de água e de fertilizante potássico na cultura de arroz irrigado. Pesquisa Agropecuária Brasileira, v. 34 , n. 4 , p. 565-573, 1999. http://dx.doi.org/10.1590/S0100204X1999000400007

VIEIRA, N. R. A. Qualidade de grãos e padrões de classificação de arroz. Informe Agropecuário, v. 25, n. 222, p. 94-100, 2004.

XIE, L. et al. Impact of proteins on pasting and cooking properties of waxy and non-waxy rice. Journal of Cereal Science, v. 47, n. 2, p. 372-379, 2007. 